\title{
Impact of Planting Methods and Plant Density on Intercropped Wheat with Sugar Beet
}

\author{
${ }^{1}$ Gomaa M.A., ${ }^{1}$ E.E. Kandil, ${ }^{2}$ A.A.M. Zen El-Dein and ${ }^{2}$ A.K.E. Abu Eisha \\ 1-Plant Production Dep., Faculty of Agriculture (Saba Basha), Alexandria University, \\ Egypt. \\ 2-Agricultural Research Center, Etay El-Baroud Research Station El-Beheira, Egypt.
}

\begin{abstract}
Two field experiments were carried out at Etay El-Baroud Research Station, El-Beheira Governorate, Agric. Res Center in 2016/2017 and 2017/2018 seasons to evaluate three planting methods and four intercropping densities of wheat with sugar beet and their interaction. The obtained results indicated that planting sugar beet on wide ridges $(120 \mathrm{~cm}$ width) and wheat on the wide of the same ridges $\left(\mathrm{M}_{1}\right)$ significantly increased yield and its components. The intercropping densities of wheat had significant effect on most of studied traits for this crop. Decrease densities of wheat lead to the highest values of all sugar beet characters and spike length of wheat, while No. of spikes $/ \mathrm{m}^{2}$, grain weight $/ \mathrm{m}^{2}$ of wheat were increased by increasing intercropping densities of wheat. A monoculture crop gave the highest values of both crops. Significant interaction effect between planting methods and intercropping plant density was found on some studied characters of the two crops under testing. Planting method intercropping combination on wide sugar beet ridges $120 \mathrm{~cm}$ width $\left(\mathrm{M}_{1}\right)$ resulted in the greatest land eqvillant ratio (LER) and gross returns. The results showed that the productivity of land increased by intercropping $12.50 \%$ of wheat seeding rate per feddan with sugar beet gave the highest LER and gross returns. The best productivity of land was achieved by planting wheat with sugar beet on sugar beet ridges $120 \mathrm{~cm}$ width $\left(\mathrm{M}_{1}\right)$ by using intercropping density $12.50 \%$.
\end{abstract}

key words: Intercropping, Sugar beet, Wheat, planting, density, intercroping

\section{INTRODUCTION}

Sugar is an essential commodity and an integral part of the 'food world and the cheapest source of energy. An overview of sugar beet (Beta vulgaris L.) indicates that it is an important commercial biennial root crop of the world, extensively grown for sugar and ethanol production. Sugar beet plant is one of the most efficient convertors of solar energy into stored energy and has great potential for augmenting sugar production at lower cost (Ahlawat et al., 2002. The cultivated area with sugar beet in Egypt was 559744 feddan yield about 11209160 ton). Wheat is one the main cereal crops, cultivated to meet the great demands of the population for bread flour in Egypt. The area of wheat in Egypt estimated about 3353151 feddan and production was 9342538 ton according to (FAO, 2017).

Intercropping wheat with sugar beet and planting methods are one of the recent agro techniques that can be employed to decrease the intercrop competition. The introduction of wide row spacing in intercropping dose not only minimal competition impacts, but also provide enough space for greater population of intercrops to achieve higher productivity. Thus, development of suitable intercropping system by evaluating the performance of wheat different row proportions with wider spacing of sugar beet $(120 \mathrm{~cm})$ is needed to increase the sugar production and net income. On the other hand, wheat was as an intercrop in sugar beet helps to augment ethanol requirement. The 
intercropping will help to improve the income per unit area by increasing yield and its components of crop like sugar beet and reducing fertilizer requirements, which will ultimately enhance the economic status of growers and sugar productivity (Gao et al., 2014; Kumar et al., 2014; Salama et al., 2016; and Hamdany and El-Aassar, 2017). However, Egbe (2010) revealed that intercropping is important because it offers potential advantages for resource utilization, reduced inputs and enhanced sustainability in yield of crop. On the other hand, Farghaly et al. (2003) indicated that the highest Average values of land equivalent ratio were observed when sugar beet was intercropped with onion, while the least were found when sugar beet was intercropped with faba bean.

The objective of this investigating is to study the effect of different rows in planting methods; to study the different intercropping densities of wheat with sugar beet on growth, yield and quality of sugar beet in an intercropping system; and to study the economic benefits of such intercropping system.

\section{MATERIL AND METHODS}

Two field experiments were carried out at Etay El-Baroud Research Station El- Beheira Governorate, during 2016/2017 and 2017/2018 seasons to study the effect of three planting methods and four intercropping densities of wheat (Triticum aestivum L.) cv. Giza 94 variety with sugar beet (Beta vulgaris L.) cv. Halawa kws variety. Preceding crop was maize in both seasons. The soil texture of the experimental site was clay, having a physical composition as follows: $11.10 \%$ sand, $32.77 \%$ silt, $60.68 \%$ clay and $0.50 \%$ organic matter. The results of soil chemical analysis as follows: $\mathrm{pH} 7.75$, available $\mathrm{Ca}=6.05 \mathrm{meq} / \mathrm{L}$, available $\mathrm{Mg}=3.49 \mathrm{meq} / \mathrm{L}$, available $\mathrm{Na}=8.64 \mathrm{meq} / \mathrm{L}$ and available $\mathrm{K}=2.30$ $\mathrm{meq} / \mathrm{L}$. A split-plot design with four replications was used. The three planting methods were allocatted main plots and four different densities of wheat plants as well as sugar beet and wheat as a monoculture crop were distributed at random to sub-plots. Where, three planting methods i.e. (planting sugar beet on wide ridges $120 \mathrm{~cm}$ width on both sides and planting wheat on the width of the ridges $\left(M_{1}\right)$, planting sugar beet on ridges (60 $\mathrm{cm}$ narrow) on one side, planting wheat on one sugar beet ridge alternating with one solid sugar beet ridge the $\left(\mathrm{M}_{2}\right)$ and planting sugar beet on ridges $(60 \mathrm{~cm}$ narrow) on one side and planting wheat on the ridges $\left(\mathrm{M}_{3}\right)$ and four intercropping densities of wheat with sugar beet i.e. $6.25 \%$ of wheat density with sugar beet $\left(D_{1}\right), 12.5 \%$ of wheat density with sugar beet $\left(D_{2}\right), 25 \%$ of wheat density with sugar beet $\left(D_{3}\right)$ and $50 \%$ of wheat density with sugar beet $\left(D_{4}\right)$ and cultivation of wheat alone and sugar beet alone. In all intercropping systems and pure stand sugar beet was planted in 100\% (35000 plant/fed) density.

The number of rows in sub- plot were 4 ridges $(120 \mathrm{~cm}$ width) or 8 ridges $60 \mathrm{~cm}$ narrow, the length of ridge was $3.5 \mathrm{~m}$ (plot area was $16.8 \mathrm{~m}^{2}=1 / 250$ of feddan).All the other culture treatments were done according to the recommendation of the ministry of Agriculture and land reclamation. 
Sugar beet was planted in $30^{\text {th }}$ of October and wheat in $26^{\text {th }}$ of November in the first and second seasons, respectively. Harvesting date was $10^{\text {th }}$ and $5^{\text {th }}$ May for sugar beet and $15^{\text {th }}$ and $10^{\text {th }}$ May for wheat in the first and second seasons, respectively.

Table (1). Meteorological records of Central Laboratory for Agriculture Climate (Source: Etay El-Baroud Research Station, during 2016/2017 and 2017/2018 seasons)

\begin{tabular}{cccccccccc}
\hline $\begin{array}{c}\text { Meteorological } \\
\text { Records }\end{array}$ & \multicolumn{4}{c}{ Air temperature $\left(\mathbf{C}^{\circ}\right)$} & \multicolumn{3}{c}{$\begin{array}{c}\text { Air Relative } \\
\text { humidity (\%) }\end{array}$} \\
\hline Season & \multicolumn{3}{c}{$\mathbf{2 0 1 6 / 1 7}$} & \multicolumn{3}{c}{$\mathbf{2 0 1 7 / 1 8}$} & $\mathbf{2 0 1 6 / 1 7}$ & $\mathbf{2 0 1 7 / 1 8}$ \\
\hline Month & Aver & Min & Max & aver & Min & Max & aver & Aver \\
January & 14.45 & 6.50 & 22.40 & 15.05 & 6.0 & 24.10 & 71 & 78 \\
February & 16.55 & 7.0 & 26.10 & 17.85 & 6.1 & 28.60 & 79 & 75 \\
March & 20.75 & 9.10 & 32.40 & 21.55 & 9.0 & 34.10 & 71 & 64 \\
April & 22.70 & 9.30 & 36.10 & 24.10 & 11.0 & 37.20 & 67 & 64 \\
May & 23.78 & 10.06 & 37.67 & 25.64 & 11.9 & 39.38 & 68 & 64 \\
\hline
\end{tabular}

\section{Studied characters:}

1-Sugar beet attributes were root length $(\mathrm{cm})$, root diameter $(\mathrm{cm})$, root weight (g), root yield (ton)/fed and top yield (ton/fed). Fresh sugar beet samples taking for sucrose\% using sacharemeter according to Le-Docte (1927), and sugar yield (tons/fed) was determined according to the method of Delta Sugar Company in Kafrel-Sheikh where approximately $3.07 \%$ of the sucrose percentage is considered as a loss during industrial practices.

2-Wheat attributes were; plant height $(\mathrm{cm})$, spike length $(\mathrm{cm})$, number of spikes $/ \mathrm{m}^{2}$, grain weight $/ \mathrm{m}^{2}$, grain yield in ardabs (one ardab $=150 \mathrm{~kg} / \mathrm{fed}$ ), straw yield (tons/fed) and 1000- grain weight (g).

\section{Evaluation of intercropping characters:}

1-Land equivalent ratio (LER).

LER is considered as the sum of fractions of the intercropped yield related to their sole crop yields. It is usually assumed that the same level of management ratio must be the same for intercropping as for solid cropping. This was determined according to Willey and Soiree (1972).

$$
\mathrm{LER}=\frac{\mathrm{Yab}}{\mathrm{Yaa}}+\frac{\mathrm{Yba}}{\mathrm{Ybb}}
$$

Where: $\mathrm{Y}_{\mathrm{ab}}=$ yield of crop (a) intercropped with crop (b), $\mathrm{Y}_{\mathrm{ba}}=$ yield of crop (b) intercropped with crop (a), $\mathrm{Y}_{\mathrm{aa}}=$ yield of crop (a) as a monoculture crop, and $\mathrm{Y}_{\mathrm{bb}}=$ yield of crop (b) as a monoculture crop.

\section{2- Economic attributes:}

An economic analysis for the results of the experiments were done to investigate the variances between the different levels of studied factors to get the highest profitability of intercropping patterns compared with a monoculture crop. 
Gross income $=$ total from selling sugar beet production $\{$ (Root yield (ton) + top yield (ton)\} and wheat production $\{$ (grains at (ardab) + straw yield (tan)\}. It was worked out on the basis of local market price prevailing the harvest time of the produce were used the price of sugar beet was 570 and 700 L.E/ton of root, 100 and 150 L.E/ton of top. 540 and 570 L.E/ardab of grain and 1000 and 1400 L.E/ton of straw of wheat\} in both seasons, respectively. The statistical analysis was carried out according to Snedecor and Cochron (1967). Treatment Averages were compared by L.S.D at 0.05 level of probability. The analysis of variance (ANOVA) was computed using CoStat V 6.4 (2005) program.

\section{RESULTES AND DISCUION}

\section{A. Sugar beet.}

The results in (Table 2) indicated that studied characters were significantly affected by planting methods in both seasons, top yield (ton per fed) and sucrose $\%$ were significantly affected by planting methods in 2017/2018 season only. The planting method $\left(M_{1}\right)$ had the highest values, while $\left(M_{3}\right)$ planting method recorded the lowest values for these traits. Root length, root diameter, root weight, root yield per fed, sugar yield per fed were significantly affected by planting methods in both seasons. Planting method $\left(\mathrm{M}_{1}\right)$ had the highest values for these traits, but planting method $\left(\mathrm{M}_{3}\right)$ recorded the lowest values. These data are in agreement with those reported by (Zahoor et al., 2010).

Results in Table (2) revealed that intercropping densities of wheat plants with sugar beet had significant effect on all studied characters in both seasons except root length in the first season. Planting sugar beet in pure stand gave the tallest root length $(26.56 \mathrm{~cm})$, followed by growing sugar beet under intercropping density $\left(D_{1}\right)$. Root diameter, root weight, root yield per fed, top yield per fed, sucrose $\%$ and sugar yield per fed were significantly affected by intercropping densities of wheat with sugar beet in both seasons. The monoculture crop had the highest values for root diameter $(9.67$ and $9.96 \mathrm{~cm})$, root yield (672.96 and $670.51 \mathrm{~g})$, root yield/fed (23.567 and $23.347 \mathrm{t} / \mathrm{fed}$ ), top yield (10.281 and $9.898 \mathrm{t} / \mathrm{fed})$, sucrose \% (17.36 and 20.22\%) and sugar yield/fed (4.006 and $4.753 \mathrm{t} / \mathrm{fed}$ ), followed by planting sugar beet under intercropping density $\left(D_{1}\right)$ for these characters root diameter $(7.95 \& 8.43 \mathrm{~cm})$, root weight (533.03 \& 521.54g), root yield per fed (18.223 \& 17.891t/fed), top yield per fed (8.380 \& 8.239t/fed), sucrose\% (18.32 \& 19.78\%) and sugar yield per fed (3.318 \& 4.583t/fed), in the two seasons, respectively. While the lowest values were obtained when planting sugar beet under density $\left(D_{4}\right)$ for the pervious mentioned characters in the first and second seasons, respectively. These results are in harmony with those reported by Salama et al. (2016) who intercropped sugar beet with wheat, barley and faba bean and found that root yield (ton ha ${ }^{-1}$ ), harvest index and sugar yield (ton ha-1) of sugar beet, pure stands of sugar beet were superior for these characters followed by sugar beet intercropped with the lowest companion crops percentage. 
Table (2). Sugar beet attributes as affected by planting methods and intercropping densities of wheat in $2016 / 2017$ and $2017 / 2018$ seasons

\begin{tabular}{|c|c|c|c|c|c|c|c|c|c|c|c|c|c|c|}
\hline \multirow[t]{2}{*}{ Treatments } & \multicolumn{2}{|c|}{$\begin{array}{l}\text { Root length } \\
(\mathrm{cm})\end{array}$} & \multicolumn{2}{|c|}{$\begin{array}{c}\text { Root diameter } \\
(\mathrm{cm})\end{array}$} & \multicolumn{2}{|c|}{$\begin{array}{c}\text { Root weight } \\
(\mathrm{g})\end{array}$} & \multicolumn{2}{|c|}{$\begin{array}{c}\text { Root yield } \\
\text { (ton/fed) }\end{array}$} & \multicolumn{2}{|c|}{$\begin{array}{l}\text { Top yield } \\
\text { (ton/fed) }\end{array}$} & \multicolumn{2}{|c|}{ Sucrose(\%) } & \multicolumn{2}{|c|}{$\begin{array}{c}\text { Sugar yield } \\
\text { (ton/fed) }\end{array}$} \\
\hline & $2016 / 17$ & $2017 / 18$ & $2016 / 17$ & $2017 / 18$ & $2016 / 17$ & $2017 / 18$ & $2016 / 17$ & $2017 / 18$ & $2016 / 17$ & $2017 / 18$ & $2016 / 17$ & $2017 / 18$ & $2016 / 17$ & $2017 / 18$ \\
\hline \multicolumn{15}{|c|}{$\begin{array}{ll} & \text { Planting methods } \\
\end{array}$} \\
\hline $\mathrm{M}_{1}$ & 27.00 & 29.40 & 8.93 & 9.26 & 600.67 & 595.48 & 20.832 & 20.602 & 7.830 & 8.261 & 17.12 & 20.80 & 3.583 & 4.301 \\
\hline $\mathrm{M}_{2}$ & 22.88 & 22.20 & 7.36 & 7.56 & 546.47 & 553.63 & 18.550 & 18.715 & 8.068 & 8.137 & 17.10 & 19.40 & 3.120 & 3.261 \\
\hline $\mathrm{M}_{3}$ & 25.09 & 24.62 & 5.95 & 6.21 & 317.32 & 342.50 & 12.726 & 12.080 & 5.607 & 5.547 & 17.17 & 17.93 & 2.259 & 2.194 \\
\hline Average & 24.99 & 25.11 & 7.41 & 7.68 & 488.15 & 497.20 & 17.369 & 17.132 & 7.168 & 7.315 & 17.13 & 19.38 & 2.987 & 3.252 \\
\hline L.S.D.at5\% & 0.43 & 1.94 & 1.05 & 0.70 & 87.85 & 45.48 & 2.066 & 1.574 & NS & 0.954 & NS & 1.32 & 0.393 & 0.046 \\
\hline \multicolumn{15}{|c|}{ Intercropping densities } \\
\hline $\mathrm{D}_{1}$ & 26.84 & 26.56 & 7.95 & 8.43 & 533.03 & 521.54 & 18.223 & 17.891 & 8.380 & 8.239 & 18.32 & 19.78 & 3.318 & 4.583 \\
\hline $\mathrm{D}_{2}$ & 25.22 & 26.26 & 7.27 & 7.50 & 525.13 & 505.65 & 17.683 & 17.115 & 6.522 & 7.256 & 17.42 & 19.67 & 3.039 & 3.406 \\
\hline $\mathrm{D}_{3}$ & 23.33 & 24.34 & 6.67 & 6.68 & 433.65 & 427.78 & 15.011 & 14.737 & 5.770 & 6.152 & 16.00 & 19.11 & 2.423 & 2.841 \\
\hline $\mathrm{D}_{4}$ & 23.12 & 23.00 & 5.52 & 5.80 & 358.11 & 360.56 & 12.531 & 12.571 & 4.936 & 4.979 & 16.56 & 18.11 & 2.067 & 2.342 \\
\hline Pure stand & 26.44 & 26.88 & 9.67 & 9.96 & 672.96 & 670.51 & 23.567 & 23.347 & 10.281 & 9.898 & 17.36 & 20.22 & 4.006 & 4.753 \\
\hline Average & 24.99 & 25.41 & 7.42 & 7.67 & 504.58 & 497.21 & 17.403 & 17.132 & 7.178 & 7.305 & 17.13 & 19.38 & 2.971 & 3.585 \\
\hline L.S.D.at5\% & NS & 1.93 & 1.11 & 0.86 & 61.61 & 28.20 & 2.055 & 1.674 & 1.134 & 0.987 & 1.10 & 1.44 & 0.411 & 0.430 \\
\hline Interaction & NS & NS & NS & NS & NS & * & NS & * & * & * & NS & NS & NS & NS \\
\hline
\end{tabular}

- Planting wheat on the wide of the all ridges $\left(\mathrm{M}_{1}\right)$, planting sugar beet on ridges $(60 \mathrm{~cm}$ narrow) on the first side, planting wheat on one sugar beet ridge alternating with one solid sugar beet ridge $\left(\mathrm{M}_{2}\right)$ and planting sugar beet on rides $\left(60 \mathrm{~cm}\right.$ narrow) on first side and planting wheat on all ridges $\left(\mathrm{M}_{3}\right)$.

$-6.25 \%$ of wheat density with sugar beet $\left(D_{1}\right), 12.5 \%$ of wheat density with sugar beet $\left(D_{2}\right), 25 \%$ of wheat density with sugar beet $\left(D_{3}\right)$ and $50 \%$ of wheat density with sugar beet $\left(D_{4}\right)$ and alone to planting sugar beet and wheat (pure stand). 
Results in Table (3) revealed that root weight and root yield per fed in the first season and top yield per fed in both seasons were significantly affected by interaction. The highest values $(731.33 \mathrm{~g})$ and $(25.667 \mathrm{t} / \mathrm{fed})$ were recorded in a monoculture crop with planting method on narrow ridges $\left\{60 \mathrm{~cm}\left(\mathrm{M}_{2}\right)\right\}$, followed by planting sugar beet under intercropping density of wheat $\left(D_{1}\right)$ on wide ridges $\left\{120 \mathrm{~cm}\right.$ width $\left.\left(\mathrm{M}_{1}\right)\right\}$. Regarding to interaction in both seasons, where the highest top yield $(11.611 \& 11.701$ ton/fed) were resulted from pure stand of sugar beet planted in $60 \mathrm{~cm}$ ridge $\left(\mathrm{M}_{2}\right)$.

Table (3). Effect of interaction between planting methods and density on root weight, root yield/fed and top yield/fed in both seasons.

\begin{tabular}{cccccc}
\hline \multicolumn{2}{c}{ Treatments } & $\begin{array}{c}\text { Root weight } \\
(\mathbf{g})\end{array}$ & $\begin{array}{c}\text { Root yield } \\
\text { (ton/fed) }\end{array}$ & \multicolumn{2}{c}{$\begin{array}{c}\text { Top yield } \\
\text { (ton/fed) }\end{array}$} \\
\hline P. methods & I. densities & $\mathbf{2 0 1 7 / 1 8}$ & $\mathbf{2 0 1 7 / 1 8}$ & $\mathbf{2 0 1 6 / 1 7}$ & $\mathbf{2 0 1 7 / 1 8}$ \\
\hline \multirow{3}{*}{$\mathrm{M}_{1}$} & $\mathrm{D}_{1}$ & 629.45 & 21.708 & 9.333 & 9.800 \\
& $\mathrm{D}_{2}$ & 608.89 & 21.002 & 8.133 & 8.050 \\
& $\mathrm{D}_{3}$ & 550.96 & 18.933 & 6.800 & 7.933 \\
& $\mathrm{D}_{4}$ & 463.87 & 16.242 & 4.550 & 5.360 \\
& Pure stand & 724.22 & 25.124 & 10.333 & 10.160 \\
& Average & 595.48 & 20.602 & 7.830 & 8.261 \\
\hline \multirow{4}{*}{$\mathrm{M}_{2}$} & $\mathrm{D}_{1}$ & 599.08 & 20.222 & 9.816 & 9.310 \\
& $\mathrm{D}_{2}$ & 590.33 & 18.676 & 7.001 & 8.973 \\
& $\mathrm{D}_{3}$ & 467.48 & 15.943 & 6.233 & 5.833 \\
& $\mathrm{D}_{4}$ & 380.02 & 13.067 & 5.678 & 4.900 \\
& Pure stand & 731.33 & 25.667 & 11.611 & 11.701 \\
& Average & 553.65 & 18.715 & 8.068 & 8.143 \\
\hline $\mathrm{D}_{1}$ & 336.09 & 11.744 & 5.991 & 5.761 \\
$\mathrm{M}_{3}$ & $\mathrm{D}_{2}$ & 317.73 & 11.667 & 4.433 & 4.776 \\
& $\mathrm{D}_{3}$ & 264.89 & 9.334 & 4.278 & 4.689 \\
& $\mathrm{D}_{4}$ & 237.80 & 8.403 & 4.583 & 4.676 \\
& Pure stand & 555.99 & 19.251 & 8.750 & 7.834 \\
\hline & Average & 342.50 & 12.080 & 5.607 & 5.547 \\
\hline \multirow{2}{*}{ LSD at $5 \%$} & 48.85 & 2.081 & 1.964 & 1.709 \\
\hline
\end{tabular}

- Planting wheat on the wide of the all ridges $\left(M_{1}\right)$, planting sugar beet on ridges $(60 \mathrm{~cm}$ narrow $)$ on the first side, planting wheat on one sugar beet ridge alternating with one solid sugar beet ridge $\left(M_{2}\right)$ and planting sugar beet on rides $\left(60 \mathrm{~cm}\right.$ narrow) on first side and planting wheat on all ridges $\left(\mathrm{M}_{3}\right)$.

- $6.25 \%$ of wheat density with sugar beet $\left(D_{1}\right), 12.5 \%$ of wheat density with sugar beet $\left(D_{2}\right), 25 \%$ of wheat density with sugar beet $\left(D_{3}\right)$ and $50 \%$ of wheat density with sugar beet $\left(D_{4}\right)$ and alone to planting sugar beet and wheat (pure stand). 


\section{B. Wheat attributes:}

Results in Table (4) indicated that, plant height, spike length, 1000-grain weight and straw yield per fed were significantly affected by planting methods in $2017 / 2018$ season only. The tallest plants were obtained when wheat was sown on narrow ridges $\left(\mathrm{M}_{2}\right)$ method, while the highest straw yield per fed was recorded when wheat was sown by $\left(\mathrm{M}_{3}\right)$ method. Planting wheat on wide ridges $\left\{120 \mathrm{~cm}\left(\mathrm{M}_{1}\right)\right\}$ gave the highest values for spike length and 1000-gain weight. Number of spike $/ \mathrm{m}^{2}$, grain weight $/ \mathrm{m}^{2}$ and grain yield/fed (ardab) on the other hand, the highest number of spike $/ \mathrm{m}^{2}$ (184.44 \& 190.38spike), grain weight $/ \mathrm{m}^{2}$ (423.06 \& 415.38g) and grain yield / fed (11.96 \& 11.75ardab) for these characters resulted by planting wheat on all sugar beet ridges $\left(\mathrm{M}_{3}\right)$ method, in both seasons respectively. Hassan et al. (2005) suggested that, methods of sowing were statistically significant for plant height, No. of grains/spike, 1000grain weight and biological yield.

The results in the same Table reviled that, intercropping densities of wheat plants with sugar beet had significant effect in all studied treats of wheat except plant height in first season and spike length in the second season and 1000-grain weight in both seasons. The tallest plants were observed when wheat was grown under intercropping density $\left(D_{4}\right)$, the tallest spike length was observed when was grown wheat under intercropping density $\left(D_{1}\right)$. Number of spikes $/ \mathrm{m}^{2}$, grain weight $/ \mathrm{m}^{2}$, grain yield/fed and straw yield/fed were significantly affected by intercropping densities in 2016/2017 and 2017/2018 seasons. Planting wheat alone had the highest values in these treats, (152.63 and 159.15spike), (374.74 \& 364.78g), $10.59 \& 10.29$ ardab) and (2.393 \& 2.831ton) followed by planting wheat under intercropping density (D4), which were in the first and second seasons, respectively. Similar results were reported by Salama et al. (2016). 
Table (4). Yield, yield components of wheat as affected by planting methods and intercropping densities during 2016/2017 and 2017/2018 seasons

\begin{tabular}{|c|c|c|c|c|c|c|c|c|c|c|c|c|c|c|}
\hline \multirow[t]{2}{*}{ Treatments } & \multicolumn{2}{|c|}{ Plant height (cm) } & \multicolumn{2}{|c|}{ Spike length(cm) } & \multicolumn{2}{|c|}{ No of spikes $/ \mathrm{m}^{2}$} & \multicolumn{2}{|c|}{$\begin{array}{c}\text { Grain weight } / \mathrm{m}^{2} \\
\text { (g) }\end{array}$} & \multicolumn{2}{|c|}{$\begin{array}{c}\text { 1000-grain } \\
\text { weight } \\
\text { (g) }\end{array}$} & \multicolumn{2}{|c|}{$\begin{array}{l}\text { Grain yield } \\
\text { (ardab/fed) }\end{array}$} & \multicolumn{2}{|c|}{$\begin{array}{l}\text { Straw yield } \\
\text { (ton/fed) }\end{array}$} \\
\hline & $2016 / 17$ & $2017 / 18$ & $2016 / 17$ & $2017 / 18$ & $2016 / 17$ & $2017 / 18$ & $2016 / 17$ & $2017 / 18$ & $2016 / 17$ & $2017 / 18$ & $2016 / 17$ & $2017 / 18$ & $2016 / 17$ & $2017 / 18$ \\
\hline \multicolumn{15}{|c|}{ Planting. Methods } \\
\hline$M_{1}$ & 98.49 & 94.12 & 13.92 & 17.68 & 136.40 & 140.80 & 355.36 & 345.00 & 53.36 & $52 . .46$ & 9.93 & 9.78 & 2.861 & 2.765 \\
\hline $\mathrm{M}_{2}$ & 97.25 & 94.53 & 14.47 & 16.03 & 137.17 & 141.25 & 314.25 & 311.87 & $50 . .16$ & 48.66 & 8.84 & 8.78 & 2.643 & 2.635 \\
\hline$M_{3}$ & 98.58 & 89.28 & 13.67 & 15.39 & 184.44 & 190.38 & 423.06 & 415.38 & 50.89 & 49.91 & 11.96 & 11.75 & 3.179 & 3.147 \\
\hline Average & 98.11 & 92.64 & 14.02 & 16.37 & 152.67 & 157.48 & 364.22 & 357.42 & 51.47 & 50.34 & 10.24 & 10.10 & 2.894 & 2.849 \\
\hline LSD at $5 \%$ & NS & 2.14 & NS & 1.36 & 24.33 & 12.24 & 37.68 & 32.91 & NS & 3.02 & 0.78 & 0.56 & NS & 0.279 \\
\hline \multicolumn{15}{|c|}{ Intercropping. Densities } \\
\hline $\mathrm{D}_{1}$ & 102.40 & 89.67 & 15.86 & 16.91 & 102.06 & 108.28 & 240.76 & 237.50 & 53.70 & 52.32 & 6.87 & 6.94 & 2.197 & 2.142 \\
\hline $\mathrm{D}_{2}$ & 99.86 & 92.67 & 14.22 & 16.33 & 114.15 & 119.84 & 277.28 & 272.13 & 51.44 & 50.59 & 7.89 & 7.71 & 2.415 & 2.408 \\
\hline $\mathrm{D}_{3}$ & 98.69 & 92.75 & 14.28 & 16.75 & 131.52 & 134.37 & 326.05 & 319.90 & 51.16 & 49.54 & 9.17 & 9.02 & 2.570 & 2.625 \\
\hline $\mathrm{D}_{4}$ & 96.93 & 94.20 & 13.04 & 15.91 & 152.63 & 159.15 & 374.74 & 364.78 & 49.82 & 48.47 & 10.59 & 10.29 & 2.893 & 2.831 \\
\hline Pure stand & 92.67 & 93.93 & 12.73 & 15.92 & 263.01 & 268.52 & 602.27 & 592.75 & 51.28 & 50.81 & 16.70 & 17.02 & 4.397 & 4.238 \\
\hline Average & 98.11 & 92.64 & 14.03 & 16.36 & 152.67 & 158.03 & 364.22 & 357.41 & 51.48 & 50.35 & 10.24 & 10.20 & 2.894 & 2.849 \\
\hline LSD at $5 \%$ & NS & 2.73 & 1.16 & NS & 54.17 & 23.54 & 36.12 & 33.42 & NS & NS & 2.83 & 1.32 & 0.408 & 0.230 \\
\hline Interaction & NS & NS & * & NS & NS & 40.77 & NS & * & NS & NS & NS & * & Ns & NS \\
\hline
\end{tabular}

- Planting wheat on the wide of the all ridges $\left(\mathrm{M}_{1}\right)$, planting sugar beet on ridges $(60 \mathrm{~cm}$ narrow) on the first side, planting wheat on one sugar beet ridge alternating with one solid sugar beet ridge $\left(\mathrm{M}_{2}\right)$ and planting sugar beet on rides $\left(60 \mathrm{~cm}\right.$ narrow) on first side and planting wheat on all ridges $\left(\mathrm{M}_{3}\right)$.

$-6.25 \%$ of wheat density with sugar beet $\left(D_{1}\right), 12.5 \%$ of wheat density with sugar beet $\left(D_{2}\right), 25 \%$ of wheat density with sugar beet $\left(D_{3}\right)$ and $50 \%$ of wheat density with sugar beet $\left(\mathrm{D}_{4}\right)$ and alone to planting sugar beet and wheat (pure stand). 
The interaction between the studied factors had no significant interaction between the two factors for most of studied characters except of spike length, number of spikes $/ \mathrm{m}^{2}$, grain weight $/ \mathrm{m}^{2}$ and grain yield per fed. The tallest spikes length obtained under the lowest intercropping density $\left(D_{1}\right)$ with planting method $\left(M_{3}\right)$ in 2017/2018 season. Number of spikes $/ \mathrm{m}^{2}$, grain weight $/ \mathrm{m}^{2}$, and grain yield per fed recorded the highest value when planting wheat in solid with planting method (M3), followed by the highest intercropping density of wheat $\left(D_{4}\right)$ with the same planting method $\left(M_{3}\right)$.

Table (5). Effect of interaction between planting methods and intercropping density on yield of wheat in both seasons

\begin{tabular}{|c|c|c|c|c|c|}
\hline \multicolumn{2}{|c|}{ Treatments } & \multirow{2}{*}{$\begin{array}{c}\begin{array}{c}\text { Spike length } \\
(\mathrm{cm})\end{array} \\
2016 / 17\end{array}$} & \multirow{2}{*}{$\begin{array}{c}\begin{array}{c}\text { No of } \\
\text { spikes/m² }\end{array} \\
2017 / 18\end{array}$} & \multirow{2}{*}{$\begin{array}{c}\begin{array}{c}\text { Grain weight } \\
\left(\mathrm{g} / \mathrm{m}^{2}\right)\end{array} \\
2017 / 18\end{array}$} & \multirow{2}{*}{$\begin{array}{c}\begin{array}{c}\text { Grain yield } \\
\text { (ardab/fed) }\end{array} \\
2017 / 18\end{array}$} \\
\hline $\begin{array}{l}\text { Planting } \\
\text { methods }\end{array}$ & $\begin{array}{c}\text { Intercropping } \\
\text { densities }\end{array}$ & & & & \\
\hline \multirow{6}{*}{$M_{1}$} & $\mathrm{D}_{1}$ & 15.87 & 97.00 & 235.00 & 6.69 \\
\hline & $\mathrm{D}_{2}$ & 13.33 & 118.00 & 260.00 & 7.21 \\
\hline & $D_{3}$ & 13.53 & 135.00 & 320.00 & 9.02 \\
\hline & $\mathrm{D}_{4}$ & 13.73 & 154.00 & 340.00 & 9.91 \\
\hline & Pure stand & 13.13 & 200.00 & 570.00 & 16.08 \\
\hline & Average & 13.92 & 140.80 & 345.00 & 9.78 \\
\hline \multirow{6}{*}{$\mathrm{M}_{2}$} & $D_{1}$ & 15.33 & 79.50 & 185.83 & 5.22 \\
\hline & $\mathrm{D}_{2}$ & 14.93 & 93.18 & 220.84 & 6.32 \\
\hline & $\mathrm{D}_{3}$ & 14.94 & 107.00 & 256.67 & 7.41 \\
\hline & $\mathrm{D}_{4}$ & 13.27 & 129.89 & 296.11 & 8.34 \\
\hline & Pure stand & 14.20 & 296.67 & 599.90 & 16.63 \\
\hline & Average & 14.47 & 141.25 & 311.87 & 8.78 \\
\hline \multirow{6}{*}{$\mathrm{M}_{3}$} & $\mathrm{D}_{1}$ & 16.87 & 140.00 & 291.67 & 8.90 \\
\hline & $\mathrm{D}_{2}$ & 14.40 & 148.34 & 335.56 & 9.60 \\
\hline & $D_{3}$ & 14.67 & 161.12 & 383.00 & 10.62 \\
\hline & $\mathrm{D}_{4}$ & 12.13 & 193.56 & 458.33 & 12.61 \\
\hline & Pure stand & 10.87 & 308.89 & 608.34 & 17.02 \\
\hline & Average & 13.67 & 190.38 & 415.38 & 11.75 \\
\hline \multicolumn{2}{|c|}{ L. S. D. at $5 \%$} & 2.01 & 40.77 & 57.88 & 2.19 \\
\hline
\end{tabular}

- Planting wheat on the wide of the all ridges $\left(M_{1}\right)$, planting sugar beet on ridges $(60 \mathrm{~cm}$ narrow) on the first side, planting wheat on one sugar beet ridge alternating with one solid sugar beet ridge $\left(\mathrm{M}_{2}\right)$ and planting sugar beet on rides $\left(60 \mathrm{~cm}\right.$ narrow) on first side and planting wheat on all ridges $\left(\mathrm{M}_{3}\right)$.

- $6.25 \%$ of wheat density with sugar beet $\left(D_{1}\right), 12.5 \%$ of wheat density with sugar beet $\left(D_{2}\right), 25 \%$ of wheat density with sugar beet $\left(D_{3}\right)$ and $50 \%$ of wheat density with sugar beet $\left(D_{4}\right)$ and alone to planting sugar beet and wheat (pure stand). 


\section{Yield advantages:}

\section{C.1. Land equivalent ratio (LER):}

Results in Table (6) revealed that the highest values of LER (1.244 and $1.285)$ were recorded by planting on ridges $\left\{120 \mathrm{~cm}\left(\mathrm{M}_{1}\right)\right\}$, while the lowest values of LER (1.120 and 1.073) were recorded by planting on ridges $\{60 \mathrm{~cm}$ $\left.\left(M_{2}\right)\right\}$ in the two seasons, respectively.

Generally, results show that, land equivalent ratio (LER) exceeded unite in all intercropping combinations between sugar beet and wheat during the two seasons. Intercropping $12.50 \%$ of wheat density with sugar beet $\left(D_{2}\right)$ had the highest values (1.210 and 1.187) in the first and second seasons, respectively. (Salama et al., 2016) reported values of LER were greater than 1.00 in any intercropping system of sugar beet with wheat, barley, and faba bean, indicating an advantage of the intercropping patterns for land usage and yield gain.

\section{C.2. Gross returns (L.E. /fed):}

Data in Table (6) showed that sowing on sugar beet on ridges $\{120 \mathrm{~cm}$ width $\left(M_{1}\right)$ \} achieved the higher gross return (18167.11 and 21038.95 LE) in the first and second seasons. Generally all intercropping systems recorded gross return higher than monoculture crops in both crops in the first and second seasons. The highest gross return (18061.94 and 20953.63 LE) was achieved when sowing $12.50 \%$ wheat density with sugar beet $\left(D_{2}\right)$ in the first and second seasons respectively. The best gross return of land, as indicated by results was obtained by sowing wheat density of $12.50 \%$ with sugar beet planted on wide $\{120 \mathrm{~cm}$ width (M1) $\}$ in the first and second seasons. These results are confirmed with those recorded by Abd El-Zaher and Gendy (2014) who found that, the total income of sugar beet in all intercropping treatments was evidently higher than that of the solid plantings. 
Table (6). Interaction effect of planting methods and wheat intercropping densities on land equivalent ratio (LER) and gross returns (L.E. /fed) in both seasons

\begin{tabular}{|c|c|c|c|c|c|c|c|c|c|c|c|c|c|c|}
\hline \multirow{3}{*}{$\begin{array}{l}\text { Planting } \\
\text { methods } \\
\text { (M) }\end{array}$} & \multicolumn{14}{|c|}{ Plant density of wheat (D) } \\
\hline & \multicolumn{2}{|r|}{$\mathbf{D}_{1}$} & \multicolumn{2}{|r|}{$\mathbf{D}_{2}$} & \multicolumn{2}{|r|}{$\mathbf{D}_{3}$} & \multicolumn{2}{|r|}{$\mathbf{D}_{4}$} & \multicolumn{2}{|c|}{ Sole s. beet } & \multicolumn{2}{|c|}{ Sole wheat } & \multicolumn{2}{|c|}{ Average } \\
\hline & LER & G. ret. & LER & G. ret. & LER & G. ret. & LER & G. ret. & LER & G. ret. & LER & G. ret. & LER & G. ret. \\
\hline \multicolumn{15}{|c|}{$2016 / 2017$} \\
\hline $\mathrm{M}_{1}$ & 1.218 & 19735.44 & 1.271 & 19489.11 & 1.256 & 19565.17 & 1.232 & 19201.64 & 1.000 & 16093.68 & 1.000 & 14917.60 & 1.244 & 18167.11 \\
\hline $\mathrm{M}_{2}$ & 1.149 & 17869.23 & 1.180 & 18121.62 & 1.101 & 16802.25 & 1.047 & 16232.15 & 1.000 & 14788.26 & 1.000 & 15052.80 & 1.120 & 16477.72 \\
\hline $\mathrm{M}_{3}$ & 1.154 & 16182.18 & 1.181 & 16575.09 & 1.180 & 16517.55 & 1.192 & 16628.24 & 1.000 & 12180.09 & 1.000 & 15549.60 & 1.177 & 15605.46 \\
\hline Average & 1.174 & 17928.95 & 1.210 & 18061.94 & 1.179 & 17628.32 & 1.157 & 17354.01 & 1.000 & 14354.01 & 1.000 & 15173.33 & 1.180 & 16750.09 \\
\hline \multicolumn{15}{|c|}{$2017 / 2018$} \\
\hline $\mathrm{M}_{1}$ & 1.280 & 23041.70 & 1.284 & 23348.90 & 1.315 & 23307.80 & 1.262 & 22163.70 & 1.000 & 18602.80 & 1.000 & 15768.80 & 1.285 & 21038.95 \\
\hline $\mathrm{M}_{2}$ & 1.102 & 21245.80 & 1.108 & 20942.70 & 1.067 & 19779.90 & 1.011 & 18491.50 & 1.000 & 19137.00 & 1.000 & 16087.10 & 1.073 & 19280.67 \\
\hline $\mathrm{M}_{3}$ & 1.133 & 17913.10 & 1.170 & 18569.30 & 1.109 & 17723.30 & 1.177 & 18417.40 & 1.000 & 14259.40 & 1.000 & 16832.60 & 1.147 & 17285.80 \\
\hline Average & 1.172 & 20733.53 & 1.187 & 20953.63 & 1.164 & 20270.33 & 1.150 & 19690.87 & 1.000 & 17352.97 & 1.000 & 16229.50 & 1.168 & 19201.80 \\
\hline
\end{tabular}




\section{REFERENCES}

Abd El-Zaher, S.R. and E.K. Gendy (2014). Effect of plant density and mineral and bio-nitrogen fertilization on intercropping faba bean with sugar beet. Egypt, J. Appl. Sci., 29(7):352-366.

Ahlawat, I. P., S. Omprakash and G. S. Saini (2002). Scientific Crop Production in India. Aman Publishing House, Meerut. pp- 576.

CoStat, Ver. 6.4 (2005). Cohort software798 light house Ave. PMB320, Monterey, CA93940, and USA. Email: info@cohort.com and Website: http://www.cohort.com/DownloadCoStatPart2.html

Egbe, O. M. (2010). Effect of Plant density of intercropped soybean with tall sorghum on competitive ability of soybean and economic yield at Otobi, Benue State, Nigeria. J. Cereals and Oil seeds,1(1): 1-10.

FAO (2017). Food and Agriculture Organization database for 2017 season.

Farghaly, B. S, A. A. Zohry and S. A. A. Bassal (2003). Crops management for intercropping sugar beet with some essential crops to maximize area unit productivity. J. Agric. Sci. Mansoura Univ., 28(7):5183- 5199.

Gao, Y., Wu, P.T., X.N. Zhao and Z.K. Wang (2014). Growth, yield and nitrogen use in the wheat/maize intercropping system in an arid region in north western China. Field Crop Res., 167:19-30.

Hamdany, M. K.H. and M. R. El-Aassar (2017). Effect of intercropping three faba bean varieties with sugar beet plants on piercing sucking insect pests and associated natural enemies under ridge space and seedling rates in relation crop yield. Egypt. Acad. J. Biolog. Sci. (A. Entomology), 10(6):57- 77.

Hassan, G., A. Faiz, B. Marwat and K.B. Nwfp (2005). Effects of planting methods and tank mixed herbicides on controlling grassy and broadleaf weeds and their effect on wheat. Agric. Univ., Peshawar (Pakistan). Dept. Weed Sci A field experiment was conducted at Agricultural Research Institute,Tarnab Peshawar, Pakistan during Rabi 2001-2002.

Kumar, B., U.S.Tiwana, A.Singh and H. Ram (2014). Productivity and quality of intercropped maize (Zea mays L.) + cowpea (Vigna unguiculata L.) Walp. fodder as influenced by nitrogen and phosphorus levels. Range Management and Agroforestry, 35: 263-267.

Le-Docte, A. (1927).Commercial determined of sugar beet root using such LeDocte process Int. Sug. J. 29: 488-492. (C.F. Sugar beet Nutrition 1927 App. Sci., pub London, A.P. Drycott).

Saban, Y., A. Mehmet and E. Mustafa (2008). Identification of advantages of maize-legume intercropping over solitary cropping through competition indices in the East Mediterranean Region. Turk., J. Agric.,32:111-119.

Salama, H.S. A., D. El-S. El-Karamity and A. I. Nawar (2016). Additive intercropping of wheat, barley, and faba bean with sugar beet: impact on yield, quality and land use efficiency. Egypt. J. Agron., 38(3):413-430.

Snedecor, G.W. and W.G. Cochran (1967). Statistical Methods $7^{\text {th }}$ edition, lowa State Univ. Press, Ames, Towa, USA.

Willey, R.W. and D.S. Soiree (1972). Studies on mixture of maize and beans (Phaseolus vulgaris) with particular reverse to plant population. J. Agric. Sc. Cambridge, 79: 519-529. 
Zahoor, A., S. Paigham, M.K. Khair and Y. Sadahiro (2010). Sugar beet (Beta vulgaris L.) response to different planting methods and row geometries II: Effect on plant growth and quality. J. Food Agric. and Envi., 8 (2): 785-791.

$$
\text { الملخص العربي }
$$

\section{تأثير طرق الزراعة والكثافة النباتية للقمح المحمل على بنجر السكر}

محمود عبدالعزبز جمعة' ، عصام إسماعيل قنديل' ، عاطف عبدالجليل مسعود زين الدين'،

\section{عوض كمال أبوعيثة'}

$$
\begin{aligned}
& \text { 1-قسم الإنتاج النباتي - كلية الزراعة - سابا باثا - جامعة الإسكندرية } \\
& \text { r-مركز البحوث الزراعية - محطة البحوث الزراعية - البحيرة }
\end{aligned}
$$

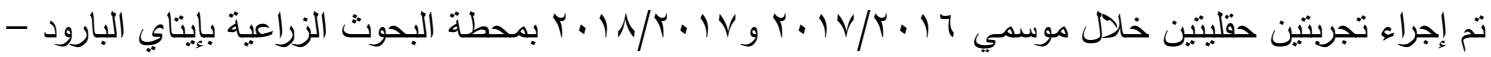

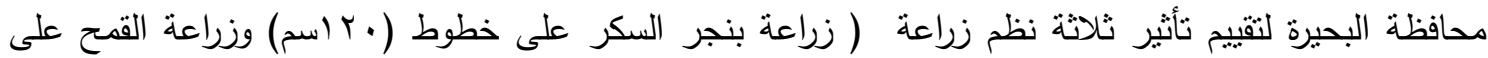
ظهر الخط(M1), زراعة بنجر السكر على خطوط (•T سم) وزراعة القمح على على خط للبنجر وترك لـك الأخر(M2) وزراعة بنجر السكر على خطوط (•آسم) وزراعة القمح على كل خطوط البنجر (M3). وأربع

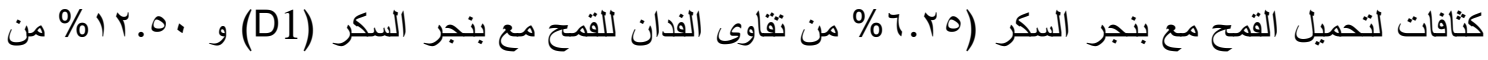

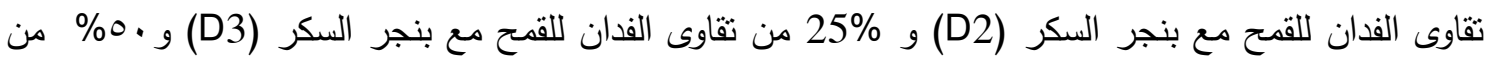
تقاوى الفدان للقمح مع بنجر السكر (D4) بالإضافة إلي زراعة بنجر السكر منفردا وزراعة القمح منفردا. وكانت زراعة بنجر السكر ... 1. في كل المعاملات.

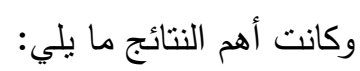

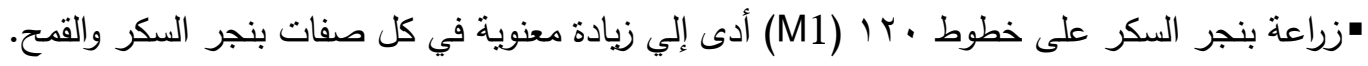

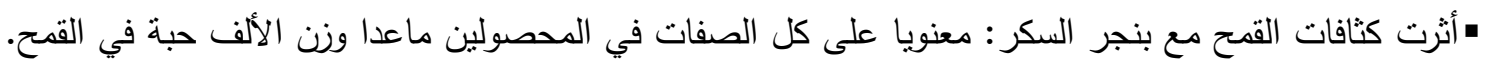

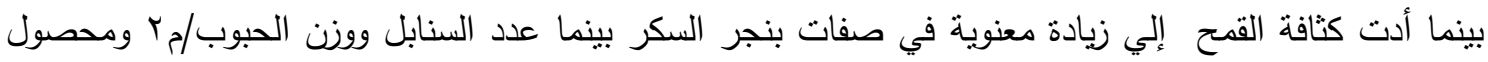
حبوب وقش الفدان من القمح زاد بزيادة كثافة القمح. الزراعة المنفردة أعطت أعلى القئل القيم في كلا المحصولين.

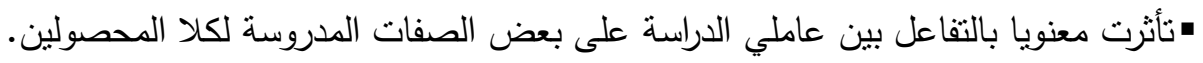

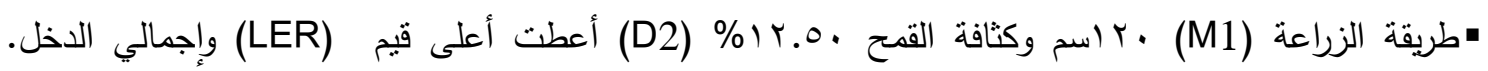

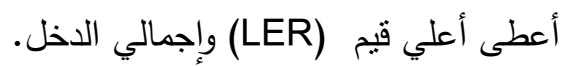

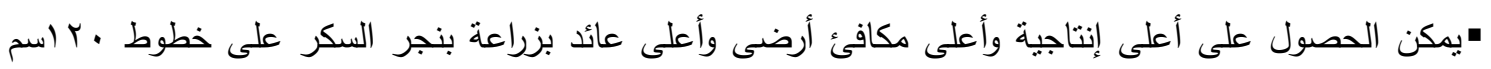

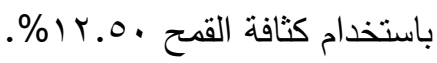


